British team which investigated German chemical warfare research. Following the post-war reorganization of the Ministry of Supply, he was appointed in 1949 director of-chemical defence research and development, and his long experience and intimate knowledge of chemical defence gained him an international reputation in this field.

Mr. E. E. Haddon

Mr. E. E. HADDON, whose promotion to deputy chief scientific officer and appointment as director of chemical defence research and development at the age of forty-eight was recently announced by the Ministry of Supply, was educated at Archbishop Holgates Grammar School, York, and at the University of London, where he graduated with honours in chemistry in 1929. In that year he entered government service as a research assistant in the then Chemical Warfare Research Department of the War Office. He was transferred to the Ministry of Supply on its creation in 1938 and throughout the War served on the headquarters staff of the Controller of Chemical Defence Kesearch and Development. In 1943, Mr. Haddon was elected a Fellow of the Royal Institute of Chemistry and in 1945 was promoted to senior principal scientific officer to take charge of the secretariat to the Ministry of Supply Scientific Advisory Council and its I'echnical Information Bureau. He returned to the Chemical Defence Branch as assistant director in 1952.

National Institute for Research in Nuclear Science

IN the House of Commons on February 14, the Financial Secretary to the Treasury announced in a written answer that, after consultation between the University Grants Committee, the Atomic Energy Authority and the Departments concerned, the Government has decided to set up a National Institute for Research in Nuclear Science. The main object of the Institute will be to provide, for common use by universities and others, facilities and equipment which are beyond the scope of individual universities and institutions carrying out research in the nuclear field. It will not replace the research now proceeding in individual universities with assistance from Government funds, nor affect the Government's participation in the international scheme for common facilities in Geneva. It is proposed to finance the Institution in the main by grants through the Atomic Energy Authority from the Lord President's Atomic Energy Vote, and provision will be made in the Estimates accordingly. Expenditure by universities will be limited to payment of the salaries and expenses of their own academic staff utilizing the research facilities provided by the Institute. The Institute will be managed by a governing board appointed jointly by the Lord President of the Council and the Chancellor of the Exchequer, and consisting of representatives of the universities, the Atomic Energy Authority, the University Grants Committee, the Royal Society and the Department of Scientific and Industrial Research, with an independent chairman; Lord Bridges has accepted appointment as chairman.

Scientific and Industrial Research Co-operation in the Commonwealth

IN reply to a question in the House of Commons on January 29, the President of the Board of Trade said that the National Research Development Corporation, which has the statutory function of developing and exploiting British inventions, is ready at all times, if requested, to give bcdies having similar objectives in Commonwealth countries the benefit of its experience. The British Productivity Council is also always willing to share its experience with other Commonwealth countries, but it would be outside its province to undertake work in British countries overseas. The Department of Scientific and Industrial Research maintains close co-operation with Commonwealth countries mainly through the agency of the British Commonwealth Scientific Offices; and as well as through the individual scientific liaison officers maintained by Commonwealth countries in the United Kingdom, there is direct collaboration between corresponding research establishments of the Department and Commonwealth Governments. The resources of the Department, which is represented on the Colonial Research Council, are available to Colonial Territories and there are Colonial research liaison officers at several of the Department's research establishments. 'The British Standards Institution also has wide contacts with Commonwealth and other countries on standardization questions, while the Colonial Development Corporation is able to draw on the advice and experience of the Department of Scientific and Industrial Research, the National Research Development Corporation and the British Productivity Council as and when required, without the need for formal liaison. Subject to Parliamentary approval and to satisfactory arrangements under discussion for the future financing of the Agency, the Government has offered to contribute up to $£ 150,000$ per annum to the cost of continuing the European Productivity Agency for a further three years from July 1, 1957.

\section{Research Collaboration between Britain and the Organization for European Economic Co-opera- tion}

THE question of research projects being carried out by the Department of Scientific and Industrial Research in co-operation with the Organization for European Economic Co-operation was raised in the House of Commons; on February 12, Mr. H. Nicholls, Parliamentary Secretary to the Ministry of Works, speaking for the Lord President of the Council, said that the Department is in direct collaboration with the European Productivity Agency of the Organization on five projects connected with aspects of building practice and in the preparation of material for conferences on automation and adaptation of the job to the worker. It is also collaborating with seven other countries in a research project on the preparation of fresh water from salt water. The five building projects were: modular co-ordination; pre-fabrication in house building; methods of organization on building sites; mechanization of certain building operations; and production and distribution of concrete on building sites. The Lord President agrees that this form of co-operation should be encouraged as one of the most effective forms of European co-operation.

\section{British Expenditure on Scientific Research and Development}

Repuying to Mr. Braine in the House of Commons on February 14, the Financial Secretary to the Treasury, Mr. J. E. Powell, said that the proportion of the gross national production spent on scientific research and development, excluding market research 